\title{
Competitive Acetylide C-C Bond Scission vs Formation of a Quadruply Bridging Carbonyl Ligand. X-ray Crystal Structures of the Two Pentanuclear Clusters $C *_{3} W_{3} R u_{2}\left(\mu_{4}-C\right)\left(\mu_{3}-C P h\right)(C O)_{9}$ and $\mathrm{Cp}_{3} \mathrm{~W}_{3} \mathrm{Ru}_{2}\left(\mu_{3}-\mathrm{CCBu}^{\mathrm{t}}\right)(\mathrm{CO})_{9}$
}

\author{
Pei-Chiun Su, ${ }^{\dagger}$ Y un Chi, ${ }^{*},{ }^{\dagger}$ Chi-J ung Su, ${ }^{\dagger}$ Shie-Ming Peng, ${ }^{*}, \star$ and \\ Gene-Hsiang Lee $\ddagger$
}

Department of Chemistry, National Tsing Hua University, Hsinchu 30043, Taiwan, and Department of Chemistry and Instrumentation Center, National Taiwan University, Taipe 10764, Taiwan

Received December 10, $1996^{\otimes}$

\begin{abstract}
Reactions of $\mathrm{Cp} * \mathrm{WRu} \mathrm{u}_{2}(\mathrm{CCPh})(\mathrm{CO})_{8}(\mathbf{l a})$ with excess $\mathrm{Cp} * \mathrm{~W}(\mathrm{CO})_{3} \mathrm{H}, \mathrm{Cp} *=\mathrm{C}_{5} \mathrm{Me}_{5}$, affords a carbido-alkylidyne cluster $\mathrm{Cp}_{3}{ }_{3} \mathrm{~W}_{3} \mathrm{Ru}_{2}\left(\mu_{4}-\mathrm{C}\right)\left(\mu_{3}-\mathrm{CPh}\right)(\mathrm{CO})_{9}(5)$ al one with three byproducts, which are identified as hydride cluster $\mathrm{Cp}^{*} \mathrm{WRu}_{3}(u-\mathrm{H})_{3}(\mathrm{CO})_{11}(\mathbf{2})$, vinylidene cluster $\mathrm{Cp}_{2} \mathrm{~W}_{2^{-}}$ $\mathrm{Ru}_{2}(\mathrm{CCHPh})(\mathrm{CO})_{9}(\mathbf{4})$, and a pentanuclear oxo-carbido cluster $\mathrm{Cp}_{2} \mathrm{~W}_{2}(\mathrm{O}) \mathrm{Ru}_{3}\left(\mu_{5}-\mathrm{C}\right)(\mathrm{CO})_{11}$ (3). In contrast, the respective condensation using tert-butyl derivative $\mathrm{Cp} * \mathrm{WRu} \mathrm{u}_{2}^{-}$ $\left(\mathrm{CCBu}^{\mathrm{t}}\right)(\mathrm{CO})_{8}(\mathbf{1 b})$ gives an acetylide cluster $\mathrm{Cp}_{3}{ }_{3} \mathrm{~W}_{3} \mathrm{Ru}_{2}\left(\mu_{3}-\mathrm{CCBu} \mathrm{C}^{\mathrm{t}}\right)(\mathrm{CO})_{9}(\mathbf{6})$. The X-ray structural determinations of $\mathbf{5}$ and $\mathbf{6}$ reveals the existence of an edge-bridged tetrahedral core, in which the butterfly crater is occupied by a $\mu_{4}$-carbide in $\mathbf{5}$ or a quadruply bridging $\mathrm{CO}$ ligand in 6. A plausible mechanism leading to the formation of these two cluster compounds is also presented.
\end{abstract}

Transition metal clusters containing unsaturated alkyne or acetylide fragments have been an area of intense investigation due to their unique physical and chemical properties ${ }^{1,2}$ and their relevance to the transformation of small hydrocarbyl intermediates on metal surfaces. Much work has been devoted to the development of this chemistry in recent years. For example, Carty and co-workers reported the syntheses and crystal structures of phosphido ruthenium clusters containing multisite bound acetylide ligands. ${ }^{3}$ Adams and coworkers focused on the hydrogenation of alkyne on the layer-segregated, face-shared bioctahedral clusters. ${ }^{4}$ Other investigations, such as the studies on the ruthenium and osmium clusters ${ }^{5}$ and the heterometallic counterparts, ${ }^{6}$ all provided substantial knowledge about the bonding and reactivity of cluster-bound alkyne and acetylide ligands.

A much less disclosed pattern of reactivity for such complexes is the $\mathrm{C}-\mathrm{C}$ bond cleavage, which affords two alkylidyne ligands from the coordinated alkynes. ${ }^{7}$ Likewise, the related acetylide ligand, which can be envis-

\footnotetext{
+ National Tsing Hua University.

₹ National Taiwan University.

${ }^{\otimes}$ Abstract published in Advance ACS Abstracts, April 1, 1997.

(1) (a) Raithby, P. R.; Rosales, M. J . Adv. Inorg. Radiochem. 1985, 29, 169. (b) Bruce, M. I.; Swincer, A. G. Adv. Organomet. Chem. 1983, 22, 59. (c) Kaesz, H. D.; Humphries, A. P. Prog. Inorg. Chem. 1979, 25, 146. (d) Sappa, E.; Tiripicchio, A.; Braunstein, P. Chem. Rev. 1983, 83, 203. (e) Sappa, E.; Tiripicchio, A.; Braunstein, P. Coord. Chem. Rev. 1985, 65, 219. (f) Bruce, M. I. Chem. Rev. 1991, 91, 197.

(2) (a) Nast, R. Coord. Chem. Rev. 1982, 47, 89. (b) Ma, L.; Williams, G. K.; Shapley, J. R. Coord. Chem. Rev. 1993, 128, 261. (c) Manna, J .; J ohn, K. D.; Hopkins, M. D. Adv. Organomet. Chem. 1995, 38, 79. (d) Chi, Y. J . Chin. Chem. Soc. 1992, 39, 591.

(3) (a) Corrigan, J . F.; Taylor, N.J .; Carty, A.J .J . Chem. Soc., Chem. Commun. 1994, 1769. (b) Sun, Y.; Taylor, N. J .; Carty, A. J . Organometallics 1992, 11, 4293.

(4) (a) Adams, R. D.; Barnard, T. S.; Li, Z.; Wu, W.; Yamamoto, J . Organometallics 1994, 13, 2357. (b) Adams, R. D.; Barnard, T. S.; Li, Z.; Wu, W.; Yamamoto, J . J . Am. Chem. Soc. 1994, 116, 9103.
}

aged as a carbide-alkylidyne in certain polynuclear systems, ${ }^{8}$ has been observed to convert to the wellseparated carbide and alkylidyne ligands. ${ }^{9}$ In this article, we focus on the irreversible acetylide cleavage through the generation of $\mathrm{Ru}_{2} \mathrm{~W}_{3}$ mixed-metal cluster, which offers an opportunity to reveal the essence of the acetylide scission vs the competing process involving the generation of the quadruply bridging $\mathrm{CO}$ ligand. ${ }^{10}$ In addition, this study supplements our previous report on the reversible acetylide cleavage between the parent acetylide cluster $\mathrm{CpWRu}_{2}(\mathrm{CCPh})(\mathrm{CO})_{8}$ and the polynuclear carbido alkylidyne derivatives $\mathrm{CpWRu}_{4}\left(\mu_{5}-\mathrm{C}\right)$ $(\mu-\mathrm{CPh})(\mathrm{CO})_{12}$ and $\mathrm{CpWRu}_{5}\left(\mu_{6}-\mathrm{C}\right)(\mu-\mathrm{CPh})(\mathrm{CO})_{14}$, which is also promoted by a cluster building reaction. ${ }^{11}$

(5) (a) Boyar, E.; Deeming, A. J .; Felix, M. S. B.; Kabir, S. E.; Adatia, T.; Bhusate, R.; M cPartlin, M.; Powell, H. R. J . Chem. Soc., Dalton Trans. 1989, 5. (b) Deeming, A. J .; Felix, M. S. B.; Bates, P. A.; Hursthouse, M. B. J. Chem. Soc., Chem. Commun. 1987, 461 . (c) Rosenberg, E. Polyhedron 1989, 8, 383. (d) Ma, L.; Rodgers, D. P. S.; Wilson, S. R.; Shapley, J . R. I norg. Chem. 1991, 30, 3591. (e) J ohnson, D. K.; Rukachaisirikul, T.; Sun, Y.; Taylor, N. J .; Canty, A.J .; Carty, A. J. Inorg. Chem. 1993, 32, 5544. (f) Haggitt, J . L.; J ohnson, B. F G.; Blake, A.J .; Parsons, S. J . Chem. Soc., Chem. Commun. 1995, 1263. (g) Paw, W.; Lake, C. H.; Churchill, M. R.; Keister, J . B. Organometallics 1995, 14, 3768. (h) Wong, W.-Y.; Chan, S.; Wong, W.-T. J . Chem. Soc., Dalton Trans. 1995, 1497. (i) Koike, M.; Hamilton, D. H.; Wilson, S. R.; Shapley, J. R. Organometallics 1996, 15, 4930. (j) Chi, Y. H wang, D.-K. In Comprehensive Organometallics Chemistry II; Wilkinson, G., Stone, F. G. A., Abel, E. W., Eds.; Pergamon: Oxford, U.K., 1995; Vol. 10, Chapter 3.

(6) (a) Roland, E.; Vahrenkamp, H. J . Mol. Catal. 1983, 21, 233. (b) Shapley, J. R.; McAteer, C. H.; Churchill, M. R.; Biondi, L. V. Organometallics 1984, 3, 1595. (c) Bernhardt, W.; Vahrenkamp, $H$. J . Organomet. Chem. 1990, 383, 357. (d) Bantel, H.; Powell, A. K.; Vahrenkamp, H. Chem. Ber. 1990, 123, 1607. (e) Adams, K. J .; Barker, J. J .; Charmant, J . P. H.; Ganter, C.; Klatt, G.; Knox, S. A. R.; Orpen, A. G.; Ruile, S. J . Chem. Soc., Dalton Trans. 1994, 477. (f) Adams, R. D.; Barnard, T.; Li, Z.; Wu, W.; Yamamoto, J . H. J . Cluster Sci. 1994 5, 551. (g) Akita, M.; Hirakawa, H.; Sakaki, K.; Moro-oka, Y. Organometallics 1995, 14, 2775. (h) Adams, H.; Bailey, N. A.; Gill, L. J .; Morris, M. J .; Wildgoose, F. A. J . Chem. Soc., Dalton Trans. 1996, 1437. (i) Norton, D. M.; Eveland, R. W.; Hutchison, J . C.; Stern, C.; Shriver, D. F. Organometallics 1996, 15, 3916. 


\section{Experimental Section}

General Information and Materials. I nfrared spectra were recorded on a Perkin-EImer 2000 FT-IR spectrometer. ${ }^{1} \mathrm{H}$ and ${ }^{13} \mathrm{C}$ NMR spectra were recorded on a Bruker AM-400, a Varian Gemini-300, or a Varian Unity-400 instrument. ${ }^{1} \mathrm{H}$ and ${ }^{13} \mathrm{C}$ NMR chemical shifts are quoted with respect to internal standard TMS. Mass spectra were obtained on a $\mathrm{J}$ EOL-HX110 instrument operating in fast atom bombardment $(F A B)$ mode. The acetylide complexes $C p^{*} W R u_{2}(C O)_{8}(C C R)$, $\mathrm{R}=\mathrm{Ph}$ and $\mathrm{Bu}^{\mathrm{t}}$, were prepared according to literature procedures. ${ }^{12}$ All reactions were performed under nitrogen using deoxygenated solvents dried with an appropriate re agent. Reactions were monitored by analytical thin-layer chromatography (5735 Kieselgel $60 \mathrm{~F}_{254}, \mathrm{E}$. Merck), and the products were separated on commercially available preparative thin-layer chromatographic plates (Kieselgel $60 \mathrm{~F}_{254}$, E. Merck). Elemental analyses were carried out at the regional instrumentation Center at National Cheng Kung University, Tainan, Taiwan.

Reaction of la with $\mathbf{C p} * \mathbf{W}(\mathbf{C O})_{3} \mathbf{H}$. A heptane solution $(80 \mathrm{~mL})$ of acetylide complex Cp*WRu ${ }_{2}(\mathrm{CCPh})(\mathrm{CO})_{8}(\mathbf{l a} ; 100$ $\mathrm{mg}, 0.118 \mathrm{mmol}$ ) and $\mathrm{Cp} * \mathrm{~W}(\mathrm{CO})_{3} \mathrm{H}(135 \mathrm{mg}, 0.334 \mathrm{mmol}$ ) was heated to reflux for $8 \mathrm{~h}$, during which the color gradually changed from orange to dark-brown. After removal of the solvent under vacuum, the residue was redissolved in $\mathrm{CH}_{2} \mathrm{Cl}_{2}$ and separated by thin-layer chromatography (silica gel, dichloromethane-hexane $3: 7)$, producing $35 \mathrm{mg}$ of the starting material $\mathrm{Cp}^{* W R u_{2}}(\mathrm{CCPh})(\mathrm{CO})_{8}(0.041 \mathrm{mmol}, 35 \%), 2 \mathrm{mg}$ of

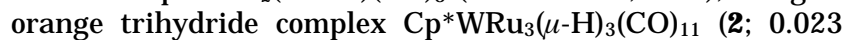
$\mathrm{mmol}, 2 \%), 6 \mathrm{mg}$ of orange-red $\mathrm{Cp}_{2} \mathrm{~W}_{2}(\mathrm{O}) \mathrm{Ru}_{3}\left(\mu_{5}-\mathrm{C}\right)(\mathrm{CO})_{11}$ (3; $0.0046 \mathrm{mmol}, 4 \%), 3 \mathrm{mg}$ of dark-brown $\mathrm{Cp}_{2}{ }_{2} \mathrm{~W}_{2} \mathrm{Ru}_{2}(\mathrm{CCHPh})-$ $(\mathrm{CO})_{9}(4 ; 0.0025 \mathrm{mmol}, 2 \%)$, and $22 \mathrm{mg}$ of black $\mathrm{Cp}_{3}{ }_{3} \mathrm{~W}_{3} \mathrm{Ru}_{2^{-}}$ $\left(\mu_{4}-\mathrm{C}\right)\left(\mu_{3}-\mathrm{CPh}\right)(\mathrm{CO})_{9}(5 ; 0.013 \mathrm{mmol}, 12 \%)$ in the order of their elution. Crystals of $\mathbf{5}$ suitable for X-ray diffraction studies were obtained by recrystallization from a layered solution of dichloromethane-methanol at room temperature.

Spectral data of 3: MS (FAB, $\left.{ }^{102} \mathrm{Ru},{ }^{184} \mathrm{~W}\right) \mathrm{m} / \mathrm{z} 1275\left(\mathrm{M}^{+}\right)$. IR ( C $\left._{6} \mathrm{H}_{12}\right) v(\mathrm{CO}), 2059$ (s), 2022 (vs), 2006 (m), 1990 (s), 1955

(7) (a) Park, J . T.; Shapley, J . R.; Churchill, M. R.; Bueno, C. J . Am. Chem. Soc. 1983, 105, 6182. (b) Gomez-Sal, M. P.;j ohnson, B. F. G.; Kamarudin, R. A.; Lewis, J.; Raithby, P. R. J . Chem. Soc., Chem. Commun. 1985, 1622. (c) Chi, Y.; Shapley, J . R. Organometallics 1985 4, 1900. (d) Eaton, B.; O'Connor, J . M.; Vollhardt, K. P. C. Organometallics 1986, 5, 394. (e) Cabrera, E.; Daran, J. C.; J eannin, Y. J . Chem. Soc., Chem. Commun. 1988, 607. (f) Stone, F. G. A.; Williams, M. L.J . Chem. Soc., Dalton Trans. 1988, 2467. (g) Park, J . T.; Shapley, J. R.; Bueno, C.; Ziller, J. W.; Churchill, M. R. Organometallics 1988, 7, 2307. (h) J ohnson, B. F. G.; Lewis, J .; Lunniss, J. A.; Braga, D.; Grepioni, F. J. Chem. Soc., Chem. Commun. 1988, 972. (i) Rumin, R. Robin, F.; Petillon, F. Y.; Muir, K. W.; Stevenson, I. Organometallics 1991, 10, 2274. (j) Braga, D.; Grepioni, F.; J ohnson, B. F. G.; Lewis, J .; Lunniss, J . A. J . Chem. Soc., Dalton Trans. 1991, 2223. (k) Braga, D.; Grepioni, F.; J ohnson, B. F. G.; Lewis, J .; Lunniss, J . A. J . Chem. Soc., Dalton Trans. 1992, 1101. (I) Shaposhnikova, A. D.; Drab, M. V.; Kamalov, G. L.; Pasynskii, A. A.; Eremenko, I. L.; N efedov, S. E.; Struchkov, Y. T.; Yanovsky, A. I. J . Organomet. Chem. 1992, 429, 109. (m) Park, J . T.; Woo, B. W.; Chung, J .-H.; Shim, S. C.; Lee, J .-H.; Lim, S.-S.; Suh, I.-H. Organometallics 1994, 13, 3384. (n) Pasynskii, A. A.; Eremenko, I. L.; Nefedov, S. E.; Kolobkov, B. I.; Shaposhnikova, A. D.; Stadnitchenko, R. A.; Drab, M. V.; Struchkov, Y. T.; Yanovsky, A. I. New J . Chem. 1994, 18, 69. (o) Quenec'h, P.; Rumin, R.; Pétillon, F. Y. J . Organomet. Chem. 1994, 479, 93. (p) Adams, H.; Cill, L. J .; Morris, M. J . Organometallics 1996, 15, 4182. (q) Adams, H.; Cill, L. J .; Morris, M. J . J . Chem. Soc., Dalton Trans. 1996, 3909.

(8) (a) Nucciarone, D.; Taylor, N. J .; Carty, A. J . Organometallics 1986, 5, 1179. (b) Blenkiron, P.; Taylor, N. J .; Carty, A. J . J . Chem. Soc., Chem. Commun. 1995, 327.

(9) (a) Wu, C.-H.; Chi, Y.; Peng, S.-M.; Lee, G.-H. J . Chem. Soc. Dalton Trans. 1990, 3025. (b) Chi, Y.; Su, P.-C.; Peng, S.-M.; Lee, G.H. Organometallics 1995, 14, 5483. (c) Chi, Y.; Chung, C.; Chou, Y.C.; Su, P.-C.; Chiang, S.-J .; Peng, S.-M.; Lee, G.-H. Organometallics 1997, 8, 1702 .

(10) (a) Horwitz, C. P.; Shriver, D. F. Adv. Organomet. Chem. 1984, 23, 219. (b) Horwitz, C. P.; Shriver, D. F. Organometallics 1984, 3, 756.

(11) Chiang, S.-J .; Chi, Y.; Su, P.-C.; Peng, S.-M.; Lee, G.-H. J . Am. Chem. Soc. 1994, 116, 11181.

(12) Hwang, D.-K.; Chi, Y.; Peng, S.-M.; Lee, G.-H. Organometallics 1990, 9, 2709. (w), $1934(\mathrm{w}), 1802(\mathrm{vw}, \mathrm{br}) \mathrm{cm}^{-1}$; IR (KBr) $v(\mathrm{~W} \equiv \mathrm{O}), 928(\mathrm{~s})$ $\mathrm{cm}^{-1}$; ${ }^{1 \mathrm{H}} \mathrm{NMR}\left(\mathrm{CDCl}_{3}, 294 \mathrm{~K}\right) \delta 2.14(\mathrm{~s}, 15 \mathrm{H}), 1.72(\mathrm{~s}, 15 \mathrm{H})$; ${ }^{13} \mathrm{C} \mathrm{NMR}\left(\mathrm{CD}_{2} \mathrm{Cl}_{2}, 200 \mathrm{~K}\right) \delta 441.5\left(\mu_{5}-\mathrm{C}, \mathrm{J} \mathrm{w}-\mathrm{C}=88\right.$ and 101 $\mathrm{Hz}), 223.0(2 \mathrm{CO}, \mathrm{br}), 212.0(2 \mathrm{CO}, \mathrm{J} w-\mathrm{c}=161 \mathrm{~Hz}), 205.8(2 \mathrm{CO}$, br), 201.4 (2CO), 199.6 (2CO, br), 192.2 (1CO), $117.1\left(\mathrm{C}_{5} \mathrm{Me}_{5}\right)$, $102.3\left(\mathrm{C}_{5} \mathrm{Me}_{5}\right), 11.6\left(\mathrm{C}_{5} \mathrm{Me}_{5}\right), 9.7\left(\mathrm{C}_{5} \mathrm{Me} \mathrm{e}_{5}\right)$. Anal. Calcd for $\mathrm{C}_{32} \mathrm{H}_{30} \mathrm{O}_{12} \mathrm{Ru}_{3} \mathrm{~W}_{2}$ : C, 30.09; $\mathrm{H}, 2.37$. Found: $\mathrm{C}, 30.03 ; \mathrm{H}, 2.47$.

Spectral data for 4: MS (FAB, $\left.{ }^{102} \mathrm{Ru},{ }^{184} \mathrm{~W}\right) \mathrm{m} / \mathrm{z} 1196\left(\mathrm{M}^{+}\right)$; IR ( $\left.\mathrm{C}_{6} \mathrm{H}_{12}\right) v(\mathrm{CO}), 2049$ (s), 2008 (vs), 1990 (m), 1976 (s), 1961 (s), 1920 (w), 1797 (vw, br), 1780 (w) cm ${ }^{-1} ;{ }^{1} \mathrm{H} \mathrm{NMR} \mathrm{(CDCl} 3$, $294 \mathrm{~K}) \delta 7.48\left(\mathrm{~d}, 2 \mathrm{H}\right.$, J $\left.\mathrm{H}_{-\mathrm{H}}=7.4 \mathrm{~Hz}\right), 7.27\left(\mathrm{t}, 2 \mathrm{H}\right.$, J $\mathrm{H}_{-\mathrm{H}}=7.4$ $\mathrm{Hz}), 7.12\left(\mathrm{t}, 1 \mathrm{H}, \mathrm{J} \mathrm{H}-\mathrm{H}^{2}=7.4 \mathrm{~Hz}\right), 6.06(\mathrm{~s}, 1 \mathrm{H}), 2.01(\mathrm{~s}, 15 \mathrm{H})$, $1.94(\mathrm{~s}, 15 \mathrm{H})$. Anal. Calcd for $\mathrm{C}_{37} \mathrm{H}_{36} \mathrm{O}_{9} \mathrm{Ru}_{2} \mathrm{~W}_{2}$ : C, 37.20; $\mathrm{H}$, 3.04. Found: $C, 37.45 ; H, 3.16$.

Spectral data for 5: MS (FAB, $\left.{ }^{102} \mathrm{Ru},{ }^{184} \mathrm{~W}\right) \mathrm{m} / \mathrm{z} 1514\left(\mathrm{M}^{+}\right)$; IR ( $\left.\mathrm{C}_{6} \mathrm{H}_{12}\right) v(\mathrm{CO}), 1994$ (w), 1971 (vs), 1936 (s), 1929 (m), 1918 (w), $1909(\mathrm{w}), 1863(\mathrm{vw}, \mathrm{br}), 1762(\mathrm{~m}) \mathrm{cm}^{-1} ;{ }^{1} \mathrm{H} \mathrm{NMR}\left(\mathrm{CDCl}_{3}\right.$, $294 \mathrm{~K}) \delta 7.48(\mathrm{~d}, 1 \mathrm{H}$, J $\mathrm{H}-\mathrm{H}=7.5 \mathrm{~Hz}), 7.25-7.09(\mathrm{~m}, 3 \mathrm{H}), 7.00$ $(\mathrm{t}, 1 \mathrm{H}, \mathrm{J} \mathrm{H}-\mathrm{H}=7.0 \mathrm{~Hz}), 2.14(\mathrm{~s}, 15 \mathrm{H}), 1.81(\mathrm{~s}, 15 \mathrm{H}), 1.74(\mathrm{~s}$, $15 \mathrm{H}) ;{ }^{13} \mathrm{C} \mathrm{NMR}\left(\mathrm{CD}_{2} \mathrm{Cl}_{2}, 294 \mathrm{~K}\right) \mathrm{CO}, \delta 251.6(\mathrm{~J} \mathrm{w}-\mathrm{C}=120 \mathrm{~Hz})$, $239.5(\mathrm{~J} \mathrm{w}-\mathrm{c}=170 \mathrm{~Hz}), 220.1(\mathrm{~J} \mathrm{w}-\mathrm{c}=167 \mathrm{~Hz}), 218.4(\mathrm{~J} \mathrm{w}-\mathrm{c}$ $=160 \mathrm{~Hz}), 218.0(\mathrm{~J} \mathrm{w}-\mathrm{c}=160 \mathrm{~Hz}), 210.0,209.6,208.2,208.0$; $\delta 402.0\left(\mu_{4}-\mathrm{C}, \mathrm{J} w-\mathrm{c}=119 \mathrm{~Hz}\right), 280.3\left(\mu_{3}-\mathrm{CPh}, \mathrm{J} w-\mathrm{c}=96\right.$ $\mathrm{Hz}), 160.9\left(\mathrm{i}-\mathrm{C}_{6} \mathrm{H}_{5}\right), 130.1(\mathrm{CH}), 128.7(\mathrm{CH}), 126.3(\mathrm{CH})$, $126.0(\mathrm{CH}), 124.8(\mathrm{CH}), 106.6\left(\mathrm{C}_{5} \mathrm{Me}_{5}\right), 106.0\left(\mathrm{C}_{5} \mathrm{Me}_{5}\right), 101.0$ $\left(\mathrm{C}_{5} \mathrm{Me}_{5}\right), 11.3$ ( $\left.\left.\mathrm{C}_{5} \mathrm{Me}_{5}\right), 10.8\left(\mathrm{C}_{5} \mathrm{Me}\right)_{5}, 10.2\left(\mathrm{C}_{5} \mathrm{Me}\right)_{5}\right)$. Anal. Calcd for $\mathrm{C}_{47} \mathrm{H}_{50} \mathrm{O}_{9} \mathrm{Ru}_{2} \mathrm{~W}_{3} \cdot{ }_{1}{ }_{2} \mathrm{CHCl}_{3}$ : C, 36.29; $\mathrm{H}, 3.24$. Found: $\mathrm{C}$, 36.00; H, 3.23.

Reaction of $\mathbf{2}$ with $\mathbf{C p} * \mathbf{W}(\mathbf{C O})_{3} \mathbf{H}$. A toluene solution (25 $\mathrm{mL})$ of 2 (11.4 mg, $0.0122 \mathrm{mmol}$ ) and $\mathrm{Cp} * \mathrm{~W}(\mathrm{CO})_{3} \mathrm{H}(26 \mathrm{mg}$, $0.065 \mathrm{mmol}$ ) was brought to reflux under nitrogen. The heating was continued for $4 \mathrm{~h}$, during which $(20 \mathrm{mg} \times 3)$ of $\mathrm{Cp} * \mathrm{~W}(\mathrm{CO})_{3} \mathrm{H}$ was added into the mixture on the hour. After removal of the solvent in vacuo, the residue was taken up in $\mathrm{CH}_{2} \mathrm{Cl}_{2}$ and separated by thin-layer chromatography (silica gel, dichloromethane-hexane 1:5), producing $5.5 \mathrm{mg}$ of orangered $3(0.004 \mathrm{mmol}, 30 \%)$ and $6 \mathrm{mg}$ of unreacted starting material 2 (52\%).

Reaction of $\mathbf{4}$ with $\mathbf{C p} * \mathbf{W}(\mathbf{C O})_{3} \mathbf{H}$. A toluene solution (15 $\mathrm{mL}$ ) of vinylidene complex 4 (9.3 $\mathrm{mg}, 0.0078 \mathrm{mmol})$ and $\mathrm{Cp} * \mathrm{~W}$ $(\mathrm{CO})_{3} \mathrm{H}(15.7 \mathrm{mg}, 0.039 \mathrm{mmol})$ was heated to reflux for $90 \mathrm{~min}$. After removal of the solvent in vacuo, the residue was separated by thin-layer chromatography (silica gel, dichloromethane-hexane 1:5), producing $8.5 \mathrm{mg}$ of black 5 (0.0056 $\mathrm{mmol}, 72 \%)$.

Reaction of $\mathbf{l b}$ with $\mathbf{C p} * \mathbf{W}(\mathbf{C O})_{3} \mathbf{H}$. A heptane solution $(60 \mathrm{~mL})$ of acetylide complex $\mathrm{CpWRu}_{2}\left(\mathrm{CCBu}^{\mathrm{t}}\right)(\mathrm{CO})_{8}(\mathbf{1 b} ; 50 \mathrm{mg}$, $0.061 \mathrm{mmol})$ and $\mathrm{Cp} * \mathrm{~W}(\mathrm{CO})_{3} \mathrm{H}(73 \mathrm{mg}, 0.18 \mathrm{mmol})$ was heated to reflux for $8 \mathrm{~h}$ under nitrogen, during which the color gradually changed from orange to dark-brown. After removal of the solvent in vacuo, the residue was redissolved in $\mathrm{CH}_{2} \mathrm{Cl}_{2}$ and separated by thin-layer chromatography (silica gel, dichloromethane-hexane 1:3), producing $16 \mathrm{mg}$ of the starting material $\mathbf{1 b}(0.019 \mathrm{mmol}, 32 \%)$, and $14 \mathrm{mg}$ of black $\mathrm{Cp}_{3} \mathrm{~W}_{3^{-}}$ $\mathrm{Ru}_{2}\left(\mu_{3}-\mathrm{CCBu}^{\mathrm{t}}\right)(\mathrm{CO})_{9}(\mathbf{6} ; 0.0094 \mathrm{mmol}, 15 \%)$. Crystals of 6 suitable for $\mathrm{X}$-ray diffraction studies were obtained by recrystallization from a layered solution of dichloromethanemethanol at room temperature.

Spectral data for 6: MS (FAB, $\left.{ }^{102} \mathrm{Ru},{ }^{184} \mathrm{~W}\right) \mathrm{m} / \mathrm{z} 1494\left(\mathrm{M}^{+}\right)$; IR ( $\left.\mathrm{C}_{6} \mathrm{H}_{12}\right) v(\mathrm{CO}), 2004$ (s), 1972 (vs), 1955 (s), 1930 (vw), 1916 (m), 1871 (vw), 1836 (w, br), 1673 (w, br) cm-1; ${ }^{1} \mathrm{H}$ NMR $\left(\mathrm{CDCl}_{3}, 294 \mathrm{~K}\right) \delta 2.14(\mathrm{~s}, 15 \mathrm{H}), 1.99(\mathrm{~s}, 15 \mathrm{H}), 1.98(\mathrm{~s}, 15 \mathrm{H})$, $1.51(\mathrm{~s}, 9 \mathrm{H}) ;{ }^{13} \mathrm{C} \mathrm{NMR}\left(\mathrm{CD}_{2} \mathrm{Cl}_{2}, 294 \mathrm{~K}\right) \mathrm{CO}, \delta 287.2(\mathrm{~J} \mathrm{w}-\mathrm{C}=$ $161 \mathrm{~Hz}), 285.6(\mathrm{~J} w-\mathrm{c}=160 \mathrm{~Hz}), 234.5(\mathrm{~J} \mathrm{w}-\mathrm{c}=184 \mathrm{~Hz}), 230.1$ $(\mathrm{J} \mathrm{w-C}=171 \mathrm{~Hz}), 219.5(\mathrm{~J} \mathrm{w}-\mathrm{C}=144 \mathrm{~Hz}), 207.6,202.5,201.4$, 198.8; $\delta 174.9\left(\mathrm{CCBu}^{\mathrm{t}}, \mathrm{J} \mathrm{w}_{-\mathrm{C}}=134 \mathrm{~Hz}\right), 144.1\left(\mathrm{CCBu}^{\mathrm{t}}\right), 105.8$ $\left(\mathrm{C}_{5} \mathrm{Me}_{5}\right), 103.6\left(\mathrm{C}_{5} \mathrm{Me}_{5}\right), 103.3\left(\mathrm{C}_{5} \mathrm{Me}_{5}\right), 41.5$ ( $\left.\mathrm{CMe}_{3}\right), 37.1$ (Me), $12.2\left(\mathrm{C}_{5} \mathrm{Me}_{5}\right), 11.3\left(\mathrm{C}_{5} \mathrm{Me}_{5}\right), 9.6\left(\mathrm{C}_{5} \mathrm{Me}_{5}\right)$. Anal. Calcd for $\mathrm{C}_{46} \mathrm{H}_{56} \mathrm{Cl}_{2} \mathrm{O}_{9} \mathrm{Ru}_{2} \mathrm{~W}_{3}: \mathrm{C}, 35.02 ; \mathrm{H}$, 3.58. Found: $\mathrm{C}, 35.14 ; \mathrm{H}$, 3.57.

X-ray Crystallography. The X-ray diffraction measurements were carried out on a Nonius CAD-4 diffractometer. 
Table 1. Crystal Data for the X-ray Diffraction Studies of Complexes 5 and $6^{a}$

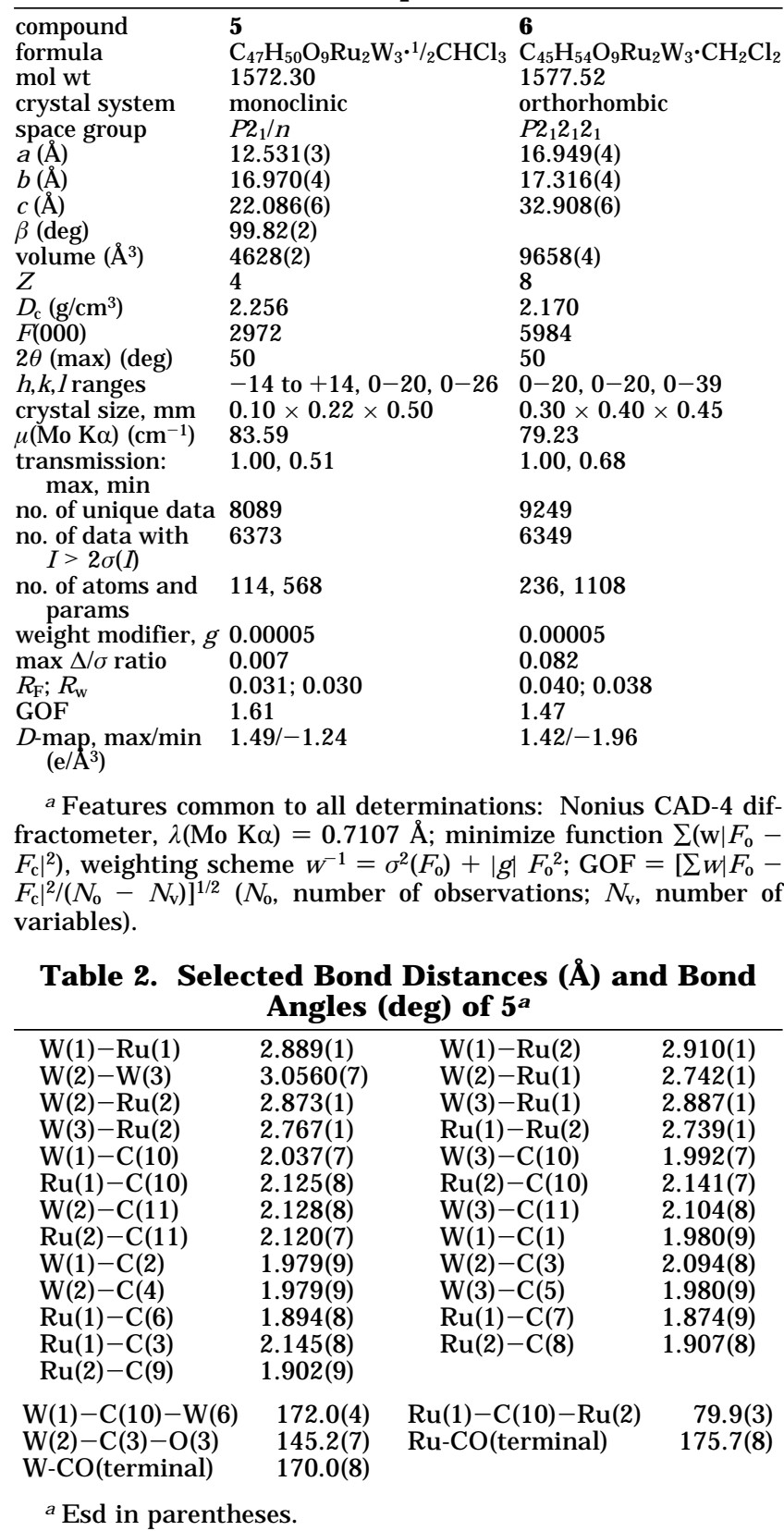

Lattice parameters were determined from 25 randomly selected high-angle reflections. Three standard reflections were monitored every 3600 s. No significant change in intensities, due to crystal decay, was observed over the course of all data collection. Intensities of the diffraction signals were corrected for Lorentz, polarization, and absorption effects ( $\psi$ scans). The structure was solved by using the NRCC-SDP-VAX package. All the non-hydrogen atoms had anisotropic temperature factors, and the hydrogen atoms of the organic functional groups were placed at idealized positions with $\mathrm{U}_{\mathrm{H}}=\mathrm{U}_{\mathrm{C}}+0.1$. The crystallographic refinement parameters of complexes 5 and $\mathbf{6}$ are given in Table 1, while their selective bond distances and angles are presented in Tables 2 and 3, respectively.

\section{Results}

Treatment of acetylide cluster $\mathrm{Cp}^{*} \mathrm{WRu}_{2}(\mathrm{CCPh})(\mathrm{CO})_{8}$ (1a) with excess $\mathrm{Cp} * \mathrm{~W}(\mathrm{CO})_{3} \mathrm{H}$ in refluxing heptane solution for $8 \mathrm{~h}$ afforded four cluster complexes in low to moderate yields. These complexes included orange trihydride complex 2 (2\%), orange-red, oxo-carbido cluster 3 (4\%), dark-brown vinylidene cluster $\mathbf{4}(2 \%)$ and
Table 3. Selected Bond Distances $(\AA)$ and Bond Angles (deg) of 6

\begin{tabular}{llll}
\hline W(1)-Ru(1) & $2.854(2)$ & W(1)-Ru(2) & $2.921(2)$ \\
W(2)-W(3) & $3.007(1)$ & W(2)-Ru(1) & $2.883(2)$ \\
W(2)-Ru(2) & $2.824(2)$ & W(3)-Ru(1) & $2.830(2)$ \\
W(3)-Ru(2) & $2.811(2)$ & Ru(1)-Ru(2) & $2.782(2)$ \\
W(2)-C(10) & $1.97(2)$ & W(3)-C(10) & $2.13(2)$ \\
Ru(2)-C(10) & $2.26(2)$ & W(3)-C(11) & $2.22(2)$ \\
Ru(2)-C(11) & $2.31(2)$ & $\mathrm{C}(10)-C(11)$ & $1.35(3)$ \\
W(1)-C(1) & $2.49(2)$ & W(2)-C(1) & $2.00(2)$ \\
Ru(1)-C(1) & $2.18(2)$ & Ru(2)-C(1) & $2.29(2)$ \\
W(1)-O(1) & $2.10(1)$ & $\mathrm{C}(1)-\mathrm{O}(1)$ & $1.28(2)$ \\
W(1)-C(2) & $1.97(2)$ & W(1)-C(3) & $2.11(2)$ \\
W(2)-C(4) & $2.00(2)$ & W(3)-C(5) & $1.95(2)$ \\
Ru(1)-C(4) & $2.33(2)$ & Ru(1)-C(6) & $1.79(2)$ \\
Ru(1)-C(7) & $1.92(2)$ & Ru(2)-C(8) & $1.90(2)$ \\
Ru(2)-C(9) & $1.90(2)$ & & \\
W(2)-C(10)-C(11) & $157.3(15)$ & $\mathrm{C}(10)-C(11)-C(12)$ & $141.5(19)$ \\
W(2)-C(1)-O(1) & $148.0(14)$ & W(2)-C(4)-O(4) \\
Ru(1)-C(4)-O(4) & $121.9(15)$ & Ru-CO(terminal) \\
W-CO(terminal) & $167.0(20)$ & & $174.5(17)$ \\
\multicolumn{5}{c}{ a Esd in parentheses. } & &
\end{tabular}

Scheme 1
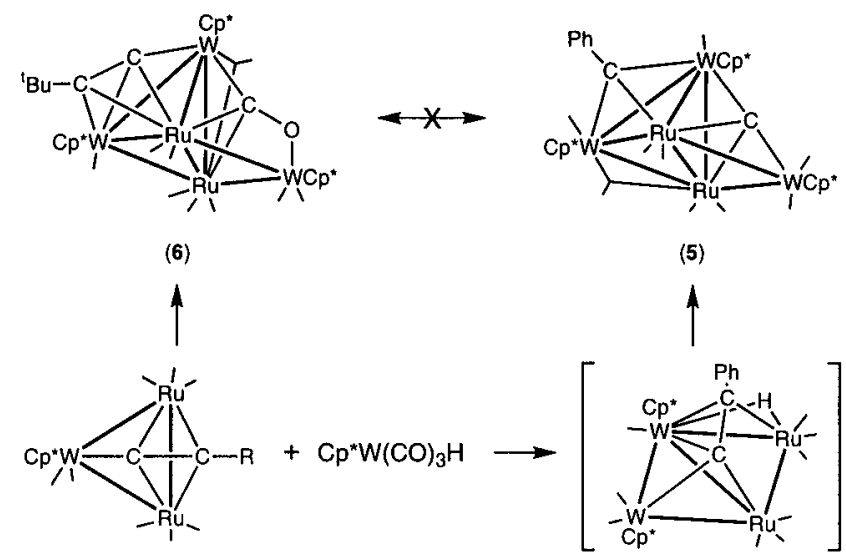

(5)

(1a) $R=P h$, (1b) $R=B u^{\prime}$

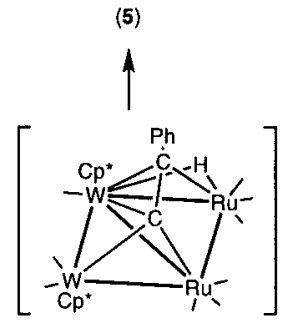

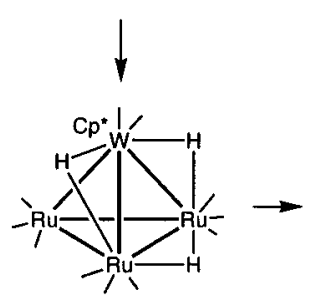

(2)

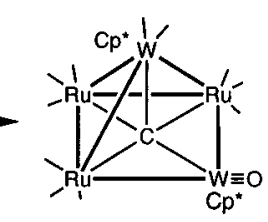

(3)

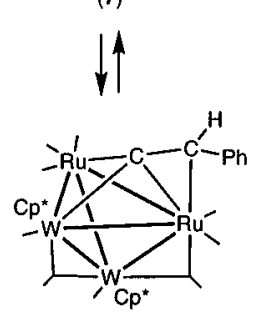

(4) black carbido-alkylidyne cluster 5 (12\%) (see Scheme 1). Each cluster complex was separated by thin-layer chromatography on silica gel and was further purified by recrystallization. The first two complexes $\mathbf{2}$ and $\mathbf{3}$ were immediately identified by comparing their IR and ${ }^{1} \mathrm{H}$ NMR data with the authentic samples prepared from the reaction of $\mathrm{Ru}_{3}(\mathrm{CO})_{12}$ and $\mathrm{Cp} * \mathrm{~W}(\mathrm{CO})_{3} \mathrm{H}, 13$ and from the condensation of the cluster $\mathrm{Cp}^{*} \mathrm{WRu}_{3}(\mu-\mathrm{H})(\mathrm{CO})_{12}$ or 2 with $\mathrm{Cp} * \mathrm{~W}(\mathrm{CO})_{3} \mathrm{H}$, respectively. ${ }^{14}$ This reactivity pattern strongly suggests that the oxo-carbido complex $\mathbf{3}$ is produced by the prior formation of the cluster $\mathrm{Cp} * \mathrm{WRu}_{3}(\mu-\mathrm{H})(\mathrm{CO})_{12}$ or $\mathbf{2}$, while the latter is generated from a parallel reaction of $\mathrm{Cp} * \mathrm{~W}(\mathrm{CO})_{3} \mathrm{H}$ with $\mathrm{Ru}_{3}(\mathrm{CO})_{12}$, and the $\mathrm{Ru}_{3}(\mathrm{CO})_{12}$ existed in the solution is most likely produced from the thermally induced decomposition of

(13) (a) Chi, Y.; Cheng, C.-Y.; Wang, S.-L. J . Organomet. Chem. 1989, 378, 45. (b) Chen, C.-C.; Chi, Y.; Peng, S.-M.; Lee, G.-H. J . Chem. Soc., Dalton Trans. 1993, 1823.

(14) Su, C.-J .; Su, P.-C.; Chi, Y.; Peng, S.-M.; Lee, G.-H. J . Am Chem. Soc. 1996, 118, 3289. 
1a. In agreement with this postulation, treatment of $\mathbf{2}$ with excess $\mathrm{Cp} * \mathrm{~W}(\mathrm{CO})_{3} \mathrm{H}$ in tolueneaffords the expected $\mathrm{Ru}_{3} \mathrm{~W}_{2}$ complex 3 in moderate yield.

The vinylidene complex $\mathbf{4}$ was established principally from its spectroscopic data. The FAB mass spectrum gave molecular ion $\mathrm{M}^{+}$due to the formula $\mathrm{Cp}_{2}{ }_{2} \mathrm{~W}_{2} \mathrm{Ru}_{2^{-}}$ (CCHPh)(CO $)_{9}$ and the peaks corresponding to successful loss of nine $\mathrm{CO}$ ligands. The IR $v(\mathrm{CO})$ spectrum shows a pattern similar to that of the structurally characterized $\mathrm{W}_{2} \mathrm{Os}_{2}$ anal ogue, ${ }^{15}$ consisting of five $\mathrm{Ru}-$ CO absorptions in the range $2050-1960 \mathrm{~cm}^{-1}$ and three broader peaks at 1920,1797, and $1780 \mathrm{~cm}^{-1}$, which we attributed to $\mathrm{W}$-bound $\mathrm{CO}$ and bridging $\mathrm{CO}$ ligands. The presence of vinylidene ligand is evident form the ${ }^{1} \mathrm{H}$ NMR data, which exhibits a singlet at $\delta 6.06$ characteristic of a $\mathrm{C}=\mathrm{CHPh}$ group, in addition to the signals of phenyl and two Cp* ligands.

Complex 5 exhibited three Cp* signals at $\delta 2.14,1.81$, and 1.74 in the ${ }^{1} \mathrm{H}$ NMR spectrum, suggesting the incorporation of three $\mathrm{Cp} * \mathrm{~W}$ fragments. The ${ }^{13} \mathrm{C}$ NMR spectrum showed four $\mathrm{Ru}-\mathrm{CO}$ resonances between the narrow range $\delta 210.0$ and 208.0 and five $\mathrm{W}-\mathrm{CO}$ resonances between $\delta 251.6$ and 218.0; the latter were established by their characteristic J $w-c$ couplings. In addition, we observed one signal at $\delta 402.0$ and a second one at $\delta 280.3$, which are best assigned to a carbido and an alkylidyne ligand, respectively. In order to confirm this hypothesis, we performed single-crystal X-ray crystallography.

According to the X-ray structural study, complex $\mathbf{5}$ is as a $\mathrm{CH}_{2} \mathrm{Cl}_{2}$ solvate. It possesses a pentametallic core of three $\mathrm{W}$ atoms and two Ru atoms coordinated by nine CO ligands, one face-bridging alkylidyne ligand and a carbide atom (Figure 1). The metal skel eton consists of an edge-bridged tetrahedral arrangement with a pendant $\mathrm{Cp} * \mathrm{~W}(1)$ unit attached to the $\mathrm{Ru}_{2} \mathrm{~W}_{2}$ tetrahedron. Alternatively, it can be considered to adopt a facebridged butterfly geometry with the C $\mathrm{p} * \mathrm{~W}(2)$ fragment coordinated to a $\mathrm{Ru}_{2} \mathrm{~W}$ metal triangle. In this molecule, all metal-metal bonds are normal with the W(2)-W(3) distance being the longest 3.0560(7) $\AA$ and the Ru(1)$\mathrm{Ru}(2)$ distance being the shortest 2.7391(11) $\AA$. Other $\mathrm{W}-\mathrm{Ru}$ distances are within the intermediate range $2.7423(10)-2.9097(10) \AA$. The variation of metal-metal bond distances is consistent with the fact that the atomic radii of the group 6 metals are slightly greater than that of the group 8 elements. A further shortening of the W(2)-Ru(1) and the W(3)-Ru(2) distances (2.7423(10) and 2.7674(10) $\AA$ ) with respect to the rest of $W-R u$ distances $(2.8734(10)-2.9097(10) \AA)$ is probably due to the influence of bridging $\mathrm{CO}$ and alkylidyne ligands.

The most important features of $\mathbf{5}$ are the carbide and alkylidyne ligands which are separated by a distance (3.13(1) $\AA$ ). The carbide atom $C(10)$ occupied the $\mathrm{Ru}_{2} \mathrm{~W}_{2}$ butterfly crater; the environment around the carbide atom is analogous to that of the tetranuclear carbide clusters reported in the literature. ${ }^{16}$ On the other hand, the alkylidyne ligand lies on the adjacent $\mathrm{RuW}_{2}$ metal triangle in a virtually symmetrical fashion, $\mathrm{W}(2)-\mathrm{C}(11)$ $=2.128(8) \AA, W(3)-C(11)=2.104(8) \AA$, and $R u(2)-$ $C(11)=2.120(7) \AA$. Its bonding is akin to that of the alkylidyne clusters $\mathrm{LWM}_{3}\left(\mu_{3}-\mathrm{CR}\right)(\mathrm{CO})_{11}, \mathrm{~L}=\mathrm{Cp}, \mathrm{Cp} *$; $\mathrm{M}=\mathrm{Os}, \mathrm{Ru} ; \mathrm{R}=\mathrm{H}, \mathrm{Ph}, \mathrm{OMe}^{16 e, 17}$ In these alkylidyne

(15) Chi, Y.; Wu, C.-H.; Peng, S.-M.; Lee, G.-H. Organometallics 1991, 10, 1676.

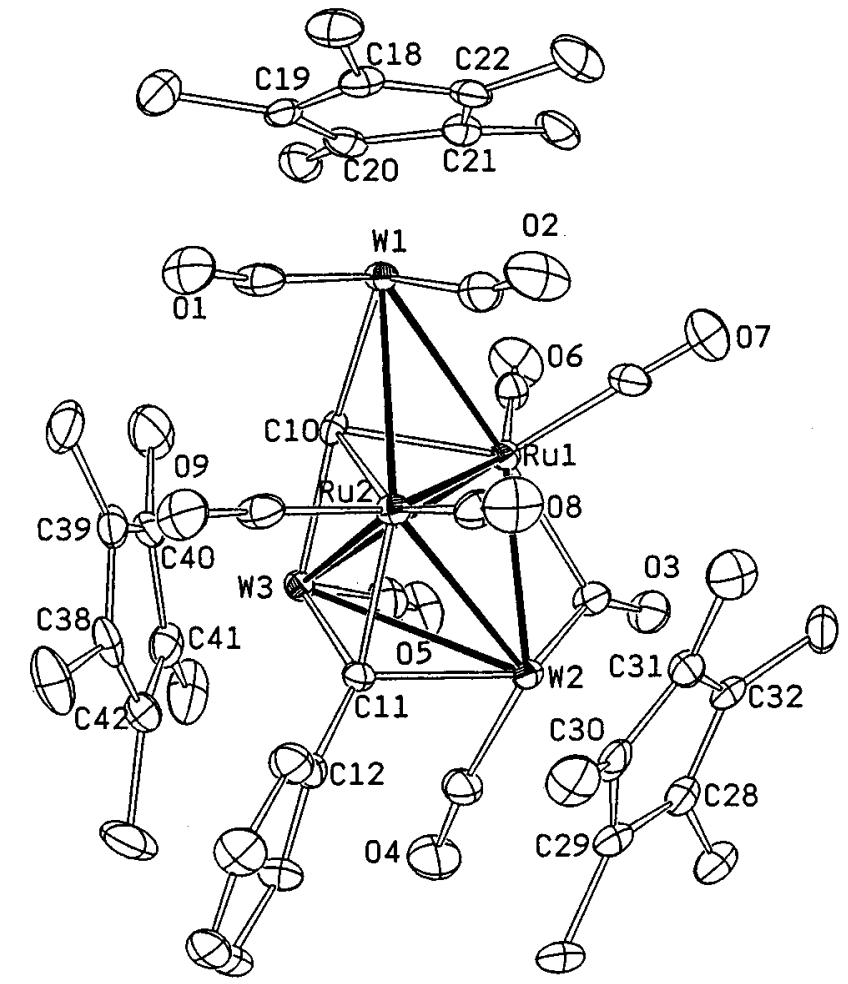

Figure 1. Molecular structure of $C \mathrm{p}^{*} \mathrm{~W}_{3} \mathrm{Ru}_{2}\left(\mu_{4}-\mathrm{C}\right)\left(\mu_{3^{-}}\right.$ $\mathrm{CPh})(\mathrm{CO})_{9}(5)$ showing the atomic labeling scheme and the thermal ellipsoids at 30\% probability level.

complexes, the face-capping alkylidyne ligand and the edge-bridging $\mathrm{CO}$ ligand are all connected to the common $\mathrm{LW}(\mathrm{CO})_{2}$ vertex. Moreover, the hexagonal face of phenyl substituent appears to possess some contact with two neighboring $\mathrm{Cp}^{*}$ ligands. Consistent with this observation, the ${ }^{13} \mathrm{C}$ NMR spectrum at room temperature showed six well-separated signals for the phenyl group, showing the preservation of such highly congested conformation even in solution state.

On the contrary, the reaction of tert-butyl derivative $\mathbf{1 b}$ and $\mathrm{Cp} * \mathrm{~W}(\mathrm{CO})_{3} \mathrm{H}$ led to the formation of acetylide complex 6 (Scheme 1). The ${ }^{1} \mathrm{H}$ NMR spectrum showed one tert-butyl group at $\delta 1.51$ and three Cp*W fragments at $\delta 2.14,1.99$, and 1.98, which agrees with the formula revealed by the $F A B$ mass analysis. In contrast, the ${ }^{13} \mathrm{C}$ NMR spectrum exhibited two high-field signals at $\delta 174.9(\mathrm{w}-\mathrm{c}=134 \mathrm{~Hz})$ and 144.1 , which are attributed to the $\mu_{3}$-acetylide ligand ${ }^{12,18}$ but not the carbide and the alkylidyne as observed in $\mathbf{5}$.

The structure of $\mathbf{6}$ was confirmed by X-ray diffraction study. It crystallizes in an orthorhombic space group $\mathrm{P} 2{ }_{1} 2_{1} 2_{1}$ with a disordered $\mathrm{CHCl}_{3}$ solvent molecule and

(16) (a) Bradley, J. S. Adv. Organomet. Chem. 1982, 22, 1. (b) Harris, S.; Bradley, J. S. Organometallics 1984, 3, 1086. (c) Hriljac, J. A.; Swepston, P. N.; Shriver, D. F. Organometallics 1985, 4, 158. (d) Hriljac, J. A.; Harris, S.; Shriver, D. F. Inorg. Chem. 1988, 27, 816. (e) Chi, Y.; Chuang, S.-H.; Chen, B.-F .; Peng, S.-M.; Lee, G.-H.J . Chem. Soc., Dalton Trans. 1990, 3033. (f) Gong, J .-H.; Tsay, C.-W.; Tu, W.C.; Chi, Y.; Peng, S.-M.; Lee, G.-H. J . Cluster S'ci. 1995, 6, 289.

(17) (a) Busetto, L.; Green, M.; Hesser, B.; Howard, J . A. K.; J effery, J . C.; Stone, F. G. A. J . Chem. Soc., Dalton Trans. 1983, 519. (b) Chi, Y.; Lee, G.-H.; Peng, S.-M.; Wu, C.-H. Organometallics 1989, 8, 1574 (c) Gong, J .-H.; Chen, C.-C.; Chi, Y.; Wang, S.-L.; Liao, F.-L. J . Chem. Soc., Dalton Trans. 1993, 1829. (d) Gong, J .-H.; Hwang, D.-K.; Tsay, C.-W.; Chi, Y.; Peng, S.-M.; Lee, G.-H. Organometallics 1994, 13, 1720.

(18) (a) Hwang, D.-K.; Chi, Y.; Peng, S.-M.; Lee, G.-H. J . Organomet. Chem. 1990, 389, C7. (b) Chi, Y.; Lee, G.-H.; Peng, S.-M.; Liu, B.-J Polyhedron 1989, 8, 2003. (c) Carty, A. J .; Cherkas, A. A.; Randall, L. H. Polyhedron 1988, 7, 1045. 


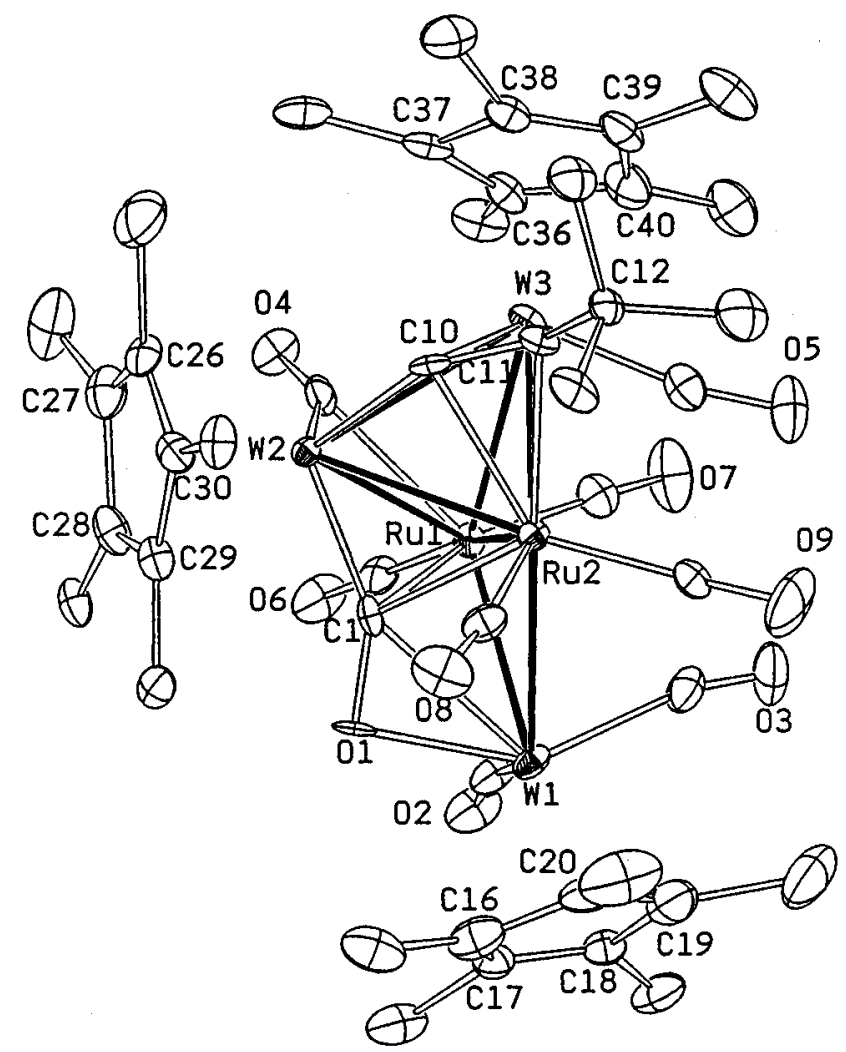

Figure 2. Molecular structure of $\mathrm{Cp}^{*}{ }_{3} \mathrm{~W}_{3} \mathrm{Ru} \mathrm{u}_{2}\left(\mu_{3}-\mathrm{CCBu} \mathrm{u}^{\mathrm{t}}\right)-$ $(\mathrm{CO})_{9}(6)$ showing the atomic labeling scheme and the thermal ellipsoids at 30\% probability level.

two crystallographically distinct, but structurally simiIar, molecules. A prospective view of one of these molecules is depicted in Figure 2. In this compound, the $\mathrm{Ru}_{2} \mathrm{~W}_{2}$ cluster core assumes a closely related edgebridged tetrahedral skeleton, on which the tert-butyl acetyli de resides on the same $\mathrm{RuW}_{2}$ face supporting the alkylidyne in 5 . The acetylide $\alpha$-carbon is found to link to $W(2)$ atom via $\alpha$-bonding, while the $C_{2}$ vector is bisecting the opposing W(3)-Ru(2) edge. The butterfly cavity is occupied by a $\mu_{4}-\mathrm{CO}$ ligand with its oxygen atom linking to the $\mathrm{Cp} * \mathrm{~W}(\mathrm{CO})_{2}$ pendent. The formation of $\mu_{4}-\mathrm{CO}$ ligand is rare in metal clusters, and only a few examples have been reported since it was first documented.19,20 Other important features of $\mathbf{6}$ involve the relocating of the bridging $\mathrm{CO}$ to the $\mathrm{W}(2)-\mathrm{Ru}(1)$ edge and the removal of terminal $\mathrm{CO}$ ligand from the W(2) atom. Such reshuffling of $\mathrm{CO}$ ligands is in response to the change of donor capacity from the alkylidyne ligand in 5 (3-electron donor) to the acetylide ligand in 6 (5-

(19) (a) Manassero, M.; Sansoni, M.; Longoni, G.; J . Chem. Soc., Chem. Commun. 1976, 919. (b) Brun, P.; Dawkins, G. M.; Green, M.; Miles, A. D.; Orpen, A. G.; Stone, F. G. A. J. Chem. Soc., Chem. Commun. 1982, 926. (c) J ohnson, B. F. G.; Lewis, J .; MCPartlin, M.; Pearsall, M.; Sironi, A. J . Chem. Soc., Chem. Commun. 1984, 1089. (d) Horwitz, C. P.; Shriver, D. F. J . Am. Chem. Soc. 1985, 107, 8147. (e) Horwitz, C. P.; Holt, E. M.; Brock, C. P.; Shriver, D. F. J . Am. Chem. Soc. 1985, 107, 8136. (f) Adams, R. D.; Babin, J . E.; Tasi, M. Angew. Chem., Int. Ed. Engl. 1987, 26, 685. (g) Adams, R. D.; Babin, J. E.; Tasi, M. Inorg. Chem. 1988, 27, 2618. (h) Wang, J .; Sabat, M.; Horwitz, C. P.; Shriver, D. F. Inorg. Chem. 1988, 27, 552. (i) Anson, C. E.; Bailey, P. J .; Conole, G.; J ohnson, B. F. G.; Lewis, J .; McPartlin, M.; Powell, H. R. J . Chem. Soc., Chem. Commun. 1989, 442

(20) (a) Chi, Y.; Wu, F.-J .; Liu, B.-J .; Wang, C.-C.; Wang, S.-L.J . Chem. Soc., Chem. Commun. 1989, 873. (b) Chi, Y.; Chuang, S.-H.; Liu, L.-K.; Wen, Y.-S. Organometallics 1991, 10, 2485. (c) Wang, J .C.; Lin, R.-C.; Chi, Y.; Peng, S.-H.; Lee, G.-H. Organometallics 1993, 12, 4061. (d) Chi, Y.; Su, C.-J .; Farrugia, L.J .; Peng, S.-H.; Lee, G.-H. Organometallics 1994, 13, 4167. (e) Su, C.-J .; Chi, Y.; Peng, S.-M.; Lee, G.-H. Organometallics 1995, 14, 4286. electron donor). Finally, the electron counting for both complexes gives 74 valence electrons, which is consistent with the prediction of pentanuclear clusters possessing eight $\mathrm{M}-\mathrm{M}$ bondings.

\section{Discussion}

This work has demonstrated that the formation of the $\mu_{4}-\mathrm{CO}$ ligand and the scission of acetylide are two competing processes which can be controlled by changing the substituents on acetylide ligand. We do not understand the actual driving force associated with change of substituents. However, it is obvious that both clusters $\mathbf{5}$ and $\mathbf{6}$ are produced through a tetranuclear $\mathrm{Ru}_{2} \mathrm{~W}_{2}$ intermediate $\mathbf{7}$ as shown in Scheme 1, which contains a hydride and an acetylide ligand. Evidence in support of this hypothesis is derived from the isolation of the $\mathrm{Ru}_{2} \mathrm{~W}_{2}$ cluster $\mathbf{4}$ in trace amount and from the observation of the thermally induced, reversible interconversion between the vinylidene and the hydrido-acetylide isomers of its $\mathrm{W}_{2} \mathrm{Os}_{2}$ analogue. ${ }^{15}$ Moreover, treatment of $\mathbf{4}$ with excess $\mathrm{Cp} * \mathrm{~W}(\mathrm{CO})_{3} \mathrm{H}$ in refluxing toluene afforded the expected pentanuclear complex $\mathbf{5}$ in high yield, which offers the ultimate confirmation. Unfortunately, we are unable to isolate the corresponding tert-butyl derivatives of $\mathbf{4}$ or $\mathbf{7}$, in a finite attempt to illustrate their involvement in the stepwise formation of the acetylide cluster $\mathbf{6}$.

The generation of the less congested, edge-bridged tetrahedral cluster core al so deserves special attention. It can be tracked back to our previous studies on the synthesis of two pentanudear complexes LWRu $u_{4}\left(\mu_{3}-\mathrm{H}\right)$ $(\mathrm{CO})_{14}{ }^{20 \mathrm{e}}$ and $\mathrm{L}_{2} \mathrm{~W}_{2} \mathrm{Ru}_{3}(\mathrm{CO})_{13}, \mathrm{~L}=\mathrm{Cp}$ and $\mathrm{Cp}^{*} .{ }^{14}$ In both cases, the $\mathrm{Cp}$ derivatives exhibit the closely packed, trigonal-bi pyramidal geometry. However, the Cp* derivatives show the formation of the same kind of edgebridged tetrahedral geometry with one $\mu_{4}$-CO ligand $20 \mathrm{e}$ or the wingtip-bridged butterfly structure containing one carbi de and one oxo ligand generating by $\mathrm{C}-\mathrm{O}$ bond cleavage. ${ }^{14}$

On the basis of these experiments, one would instinctively expect that the dominant factor in controlling the cluster core arrangement is due to the reduction of interligand repulsion imposed by the Cp* ligand. The coordinative unsaturation generated by changing from the trigonal-bipyramidal to the edge-bridged tetrahedral geometry is thus compensated by forming the $\mu_{4}-\mathrm{CO}$ ligand as observed in 6 . In the presence of ligated acetylide, such as in $\mathbf{5}$, it would give rise to the carbide and alkylidyne ligands. Clearly, study of the related $\mathrm{Cp}$ derivatives of $\mathbf{5}$ or $\mathbf{6}$ is vital to the confirmation of this assumption. However, attempts to generate the $\mathrm{Cp}$ derivatives via combining $\mathrm{CpWRu}_{2}(\mathrm{CCR})(\mathrm{CO})_{8}, \mathrm{R}=\mathrm{Ph}$, $\mathrm{Bu}^{\mathrm{t}}$, and $\mathrm{CpW}(\mathrm{CO})_{3} \mathrm{H}$ under similar conditions gave no stable products at all.

Acknowledgment. We thank the National Science Council of Taiwan, Republic of China for financial support (Grant NSC 85-2113-M007-008).

Supporting Information Available: Tables giving all bond distances and angles, atomic coordinates, and anisotropic thermal parameters for complexes 5 and $\mathbf{6}$ (26 pages). Ordering information is given on any current masthead page. 